\title{
Investigation of Electrical Conductivity Value and Cooking Homogeneity During Ohmic Cooking of Turkish Sausage
}

\author{
Serdal Sabanci \\ Munzur University, Faculty of Health Sciences, Department of Nutrition and Dietetics, Tunceli, Turkey \\ serdalsabanci@hotmail.com iD \\ Received date: 01.09.2020, Accepted date: 16.12.2020
}

\begin{abstract}
Turkish Sausage (Sucuk) is an important traditional meat product for Turkish society and is used in breakfast, grill, daily meals, and toast. Sucuk samples were cooked by heating up to $80^{\circ} \mathrm{C}$ with ohmic heating using eight different voltage gradients. The cooking process has shortened due to the increase in the voltage during ohmic cooking. It was determined that the electrical conductivity value increased as the temperature increased during ohmic cooking, and the electrical conductivity value varied between $0.51-3.38 \mathrm{~S} \mathrm{~m}^{-1}$. At the end of the ohmic cooking process, the temperature homogeneity of the samples was examined with the help of a thermal camera and it was determined that homogeneous cooking could not be provided in low voltage gradients. As a result, it was determined that the sucuk sample could be cooked with ohmic cooking and that homogeneous cooking in a high voltage gradient can be provided.
\end{abstract}

Keywords: Electrical conductivity, homogeneity, ohmic cooking, temperature

\section{Sucuk Örneklerinin Ohmik Pişirilmesi Sırasında Elektrik İletkenlik Değerinin ve Pişirme Homojenliğinin İncelenmesi}

\section{$\ddot{O} z$}

Sucuk, Türk toplumu için önemli bir geleneksel et ürünüdür ve kahvaltıda, 1zgarada, günlük yemeklerde ve tostta kullanılmaktadır. Sucuk örnekleri, sekiz farklı voltaj gradyanı kullanılarak ohmik 1sıtma ile $80{ }^{\circ} \mathrm{C}$ 'ye kadar 1 sıtılarak pişirilmiştir. Ohmik pişirme sırasında voltajın artması nedeniyle pişirme işleminin süresi kısalmıştır. Ayrıca, ohmik pişirme sırasında sıcaklık arttıkça elektriksel iletkenlik değerinin arttı̆g 1 ve elektrik iletkenlik değerinin $0.51-3.38 \mathrm{~S} \mathrm{~m}^{-1}$ arasında değiştiği tespit edilmiştir. Ohmik pişirme işlemi sonunda numunelerin sıcaklık homojenliği termal kamera yardımı ile incelenmiş ve düşük voltaj gradyanlarında homojen pişirme sağlanamadığı tespit edilmiştir. Sonuç olarak sucuk örneklerinin ohmik pişirme ile pişirilebileceği ve yüksek voltaj gradyanında homojen pişirme sağlanabileceği belirlenmiştir.

Anahtar Kelimeler: Elektriksel iletkenlik, homojenlik, ohmik pişirme, sıcaklık

\section{INTRODUCTION}

Turkish Sausage (Sucuk) is one of the essential traditional meat products for Turkish society. According to the Turkish Food Codex Meat and Meat Products Communiqué (2012/74) is defined as "It is a non-heat treated fermented meat product, whose cross-sectional surface is mosaic-treated, by fermentation and drying under certain conditions, after being mixed with flavors by mincing the meat and fats of bovine and/or ovine carcass" (TFC, 2018). Sucuk is traditionally consumed in Turkish cuisine for breakfast, meals, and fast foods (Aksu ve Kaya, 2004).
The heating principle of the ohmic heating process is based on the heat generation that occurs in the product by passing an alternating current between the two electrodes (İçier, 2003). Ohmic heating occurs volumetrically; the temperature distribution in the liquid product is homogeneous (Palaniappan and Sastry, 1991). Many researchers have examined ohmic heating in many studies in open literature such as heating (Cho et al., 2016; Halden et al., 2007), distillation (Gavahian et al., 2016), thawing (Cokgezme and İcier, 2019), cooking (Yildiz Turp et al., 2016), evaporation (Cokgezme et al., 2017), drying (Y1ldız et al., 2016), blanching (İcier, 2010), 
etc. It has been determined that the studies with ohmic cooking of meat and meat products are limited. Also, it was determined that these studies were performed on electrical conductivity, quality characteristics, and performance evaluation (Bozkurt and Icier, 2010a, 2010b; İcier et al., 2020; İcier, et al., 2014; Sarang et al., 2008; Yildiz-Turp et al., 2013; Zell et al., 009b).

The ohmic heating process has been reported by researchers as a fast, homogeneous heating and energyefficient high heating technique. The main reason for the homogeneous heating in the ohmic heating process is that the current passes homogeneously. However, since the current does not pass through the homogeneous product and the contact of the products with the electrodes is not ensured, homogeneous heating and/or cooking cannot be provided (Castro et al., 2004, İçier, 2003). It was reported that the success inhomogeneous cooking or dissolution of meat samples depends on the structural homogeneity of the samples (Bozkurt and Icier, 2010a). Sucuk, used in the current study, the sample is a meat product that contains oil, minced meat, and spices, and these products have been mixed homogeneously (Aksu ve Kaya, 2004).

In the open literature, studies determining the homogeneity of the temperature distribution of the products in the ohmic heating process are limited. Icier et al., (2017) compared the homogeneity of the thawing process by using the ohmic heating process with different thawing methods. It has been reported that the thawing process by ohmic heating is not provided homogeneously. Icier et al., (2014) provided the semicooking process by reaching the meatball samples to 75 ${ }^{\circ} \mathrm{C}$ and examined the cooking homogeneity with a thermal camera. They reported that the meatball samples had a suitable homogeneity value after the semi-cooking process. In particular, it was found that the thermal camera evaluations were given as examples in a limited voltage gradient. Therefore, it is thought that this study can make a serious contribution to the literature.

To the knowledge of the author, it has been determined that the electrical conductivity values during the cooking of meat and meat products with the ohmic cooking process and the studies related to cooking homogeneity at the end of the cooking process are limited in the open literature. The main objectives of this study are the cooking of sucuk samples using ohmic heating and determine the temperature distribution of sucuk samples during contact with and without contact during ohmic cooking. Determining the electrical conductivity value, which is an essential parameter for the ohmic heating processes during cooking, was determined as other purposes of the study.

\section{MATERIAL AND METHODS}

The sucuk samples were obtained from a local company that produces traditional products according to the Turkish Food Codex. The samples are provided from the same batch numbers to avoid differences. After the sucuk samples reached the Munzur University Laboratory, they were quickly stored in a cabinet at $+4{ }^{\circ} \mathrm{C}$.

\section{Ohmic Cooking}

The schematic representation of the ohmic cooking system was given in Figure 1. The ohmic cooking system consisted of a variac, an isolated transformer, a computer, and a custom-made microprocessor. It was made of polyoxymethylene, which consists of a rectangular cross-section with a size of $6 \times 7 \times 11 \mathrm{~cm}$ for the test cell. Electrodes used in the ohmic cooking process were made of stainless steel. In the ohmic cooking process, it was used in eight different voltage gradients in the range of 6-20 $\mathrm{V} \mathrm{cm}{ }^{-1}$. The sucuk samples were heated from $4{ }^{\circ} \mathrm{C}$ to $80{ }^{\circ} \mathrm{C}$ for cooking. Once the sucuk samples reached $80{ }^{\circ} \mathrm{C}$, the cooking process was completed. With the help of a custom-made microprocessor, current, voltage, and temperature values were recorded in seconds.

\section{Electrical Conductivity (EC)}

The sucuk sample is a meat product that contains oil, minced meat, and spices, and these products have been mixed homogeneously. However, since the current always preferred the most accessible way during the process, the electrical conductivity value obtained was expressed as an effective electrical conductivity. With the help of a custom-made microprocessor current, voltage, and temperature values had been recorded in second. 


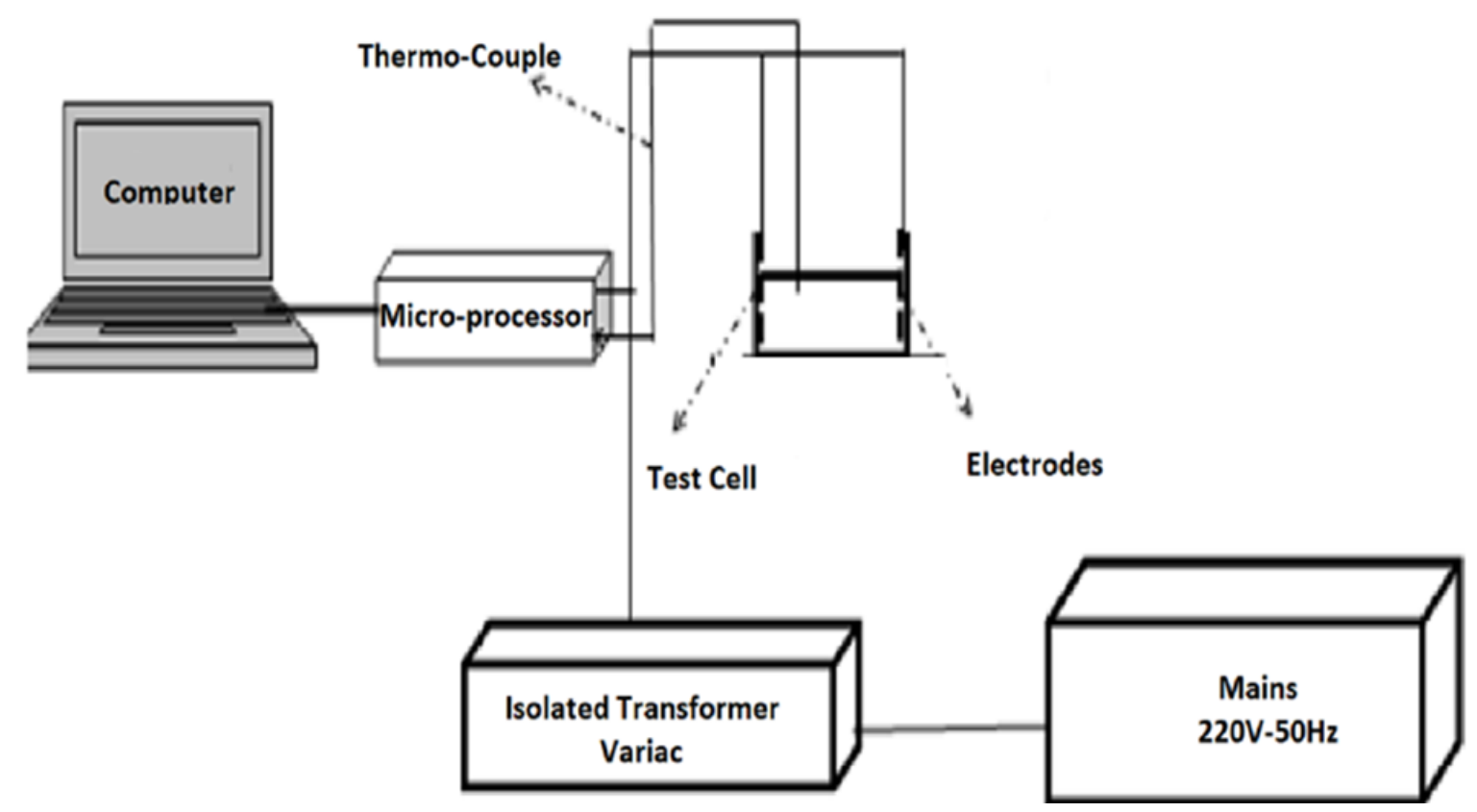

Figure 1. The schematic illustration of ohmic cooking process

The effective electrical conductivity values during the ohmic cooking process were determined by utilizing Equation 1 (Cevik and Icier, 2018).

$E C=\frac{I}{V} \times \frac{L}{A}$

Here, I represents current (Amps), V voltage (Volt), L is the length between two electrodes (m), and $A$ is the electrode surface area $\left(\mathrm{m}^{2}\right)$.

\section{Temperature Measurements}

Temperature measurements were carried out with contact and without contact during and after ohmic cooking. For contact measurements, T-type thermocouple placed in the sample center were used in seconds with a custom-made microprocessor. The contactless temperature was taken with the aid of a thermal camera for measurement purposes. When the sucuk samples are finished cooking, the sausage samples are divided into two, and their images are obtained with the thermal camera. The photographs obtained were processed with thermal image processing programs. Warm-up zones of the samples were taken, and thermal imaging programs determined their minimum, maximum, and average temperature values. Besides, the scale range was adjusted from $25^{\circ} \mathrm{C}$ to $90{ }^{\circ} \mathrm{C}$ for a better comparison of all thermal images.

\section{Statistical Evaluation}

SPSS 11.0.1 (SPSS, IBM, 2001) package program was used in the statistical evaluation of the results (One-Way ANOVA, Duncan test). The confidence level was taken as $95 \%$. During the ohmic cooking process of different voltage gradients; total cooking process time, the average effective electrical conductivity of the cooked sausage was compared statistically.

\section{RESULTS AND DISCUSSION}

The sucuk samples were heated from $4{ }^{\circ} \mathrm{C}$ to 80 ${ }^{\circ} \mathrm{C}$ with eight different voltage gradients $\left(6-20 \mathrm{~V} \mathrm{~cm}^{-}\right.$ $\left.{ }^{1}\right)$ using ohmic heating and cooking. During the ohmic cooking process, the electrical conductivity value of the sucuk samples was investigated from $4{ }^{\circ} \mathrm{C}$ to 80 ${ }^{\circ} \mathrm{C}$. The total consumed energy required for the cooking process was also determined. Also, the homogeneous temperature distribution of solid products, which appear to be an essential parameter for ohmic heating, was determined. These results were discussed in detail below.

\section{Total Ohmic Cooking Time}

During the ohmic cooking process, a change of temperature of eight different voltage gradients (6-20 $\mathrm{V} \mathrm{cm}-1$ ) of the sucuk samples depending on time is given in Figure 2. 


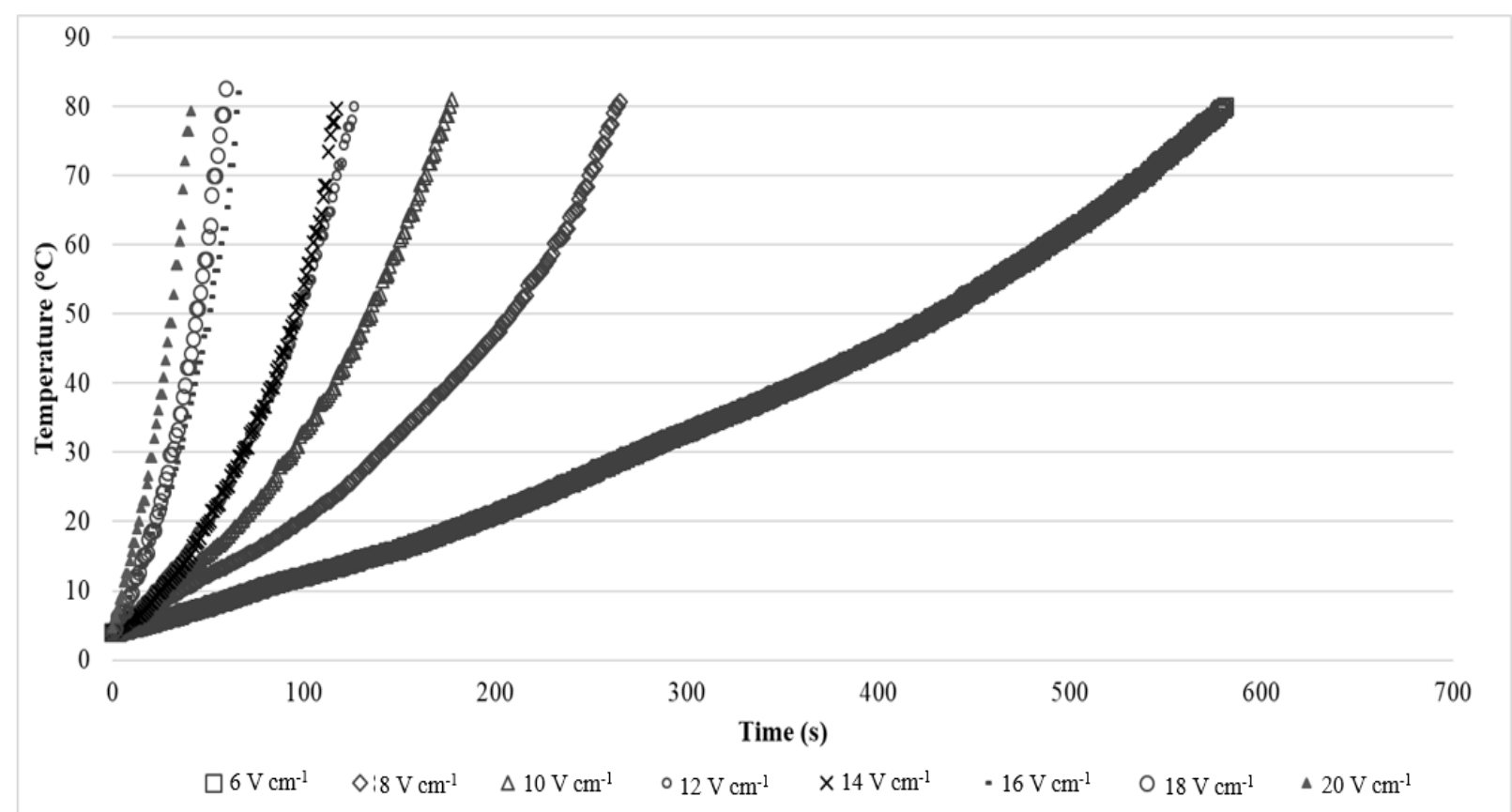

Figure 2. Change of temperature of 8 different voltage gradients $\left(6-20 \mathrm{~V} \mathrm{~cm}^{-1}\right)$ of the sucuk samples depending on time during the ohmic cooking process

Accordingly, it was determined that the total ohmic cooking time decreased as the voltage gradient increased. Especially, $6 \mathrm{~V} \mathrm{~cm}^{-1}$ was determined to be $584 \mathrm{~s}$ while this value was $126 \mathrm{~s}$ at $12 \mathrm{~V} \mathrm{~cm}^{-1}$ and 40 $\mathrm{s}$ at $20 \mathrm{~V} \mathrm{~cm}^{-1}(p<0.05)$. It was reported in many studies that the increase in the voltage gradient in the ohmic heating process increased with the square where the given volumetric heating value does not change linearly. It has been reported that the processing time decreases as the voltage gradient increases in the heating of different products (orange juice, lemon juice, pomegranate juice, strawberry juice, etc.) by using ohmic heating. Besides, the increase in the voltage gradient during the evaporation process has been reported to shorten the processing time. Similarly, it was stated that the increase in the voltage gradient affects the processing time in a positive way to solving solid products. Bozkurt and Icier, (2010b) cooked the ground beef samples with different fat content by using ohmic heating by applying different voltage gradients. They reported that the increased voltage gradient in the cooking process shortens the processing time. Also, they were determined to affect the electrical conductivity value negatively due to the increase in fat content. Özkan et al., (2004) cooked hamburger patties using conventional and combined ohmic heating and stated the processing time required for ohmic cooking as $163 \mathrm{~s}$. It has been reported by researchers that ohmic cooking is an alternative to traditional cooking (Bozkurt and Icier, 2010c; YildizTurp et al., 2013; Zell et al., 2009a).

\section{Electrical Conductivity (EC)}

The electrical conductivity value from $4{ }^{\circ} \mathrm{C}$ to $80{ }^{\circ} \mathrm{C}$ during the ohmic cooking process for eight different voltage gradients was determined and given in Figure 3. In all voltage gradient applications, it was determined that the electrical conductivity value increases as the temperature increases. Increasing molecular mobility due to the increase in temperature has been reported to cause an increase in the electrical conductivity value. However, it was found that, especially in high voltage gradient values, the increase in electrical conductivity value after critical temperature $\left(65^{\circ} \mathrm{C}\right)$ decreased. While the lowest electrical conductivity value was obtained as $0.51 \mathrm{~S} \mathrm{~m}^{-1}$ for $14 \mathrm{~V} \mathrm{~cm}^{-1}$ during cooking, the highest electrical conductivity value was $3.38 \mathrm{~S} \mathrm{~m}^{-1}$ for $16 \mathrm{~V} \mathrm{~cm}^{-1}$. It was given in Figure 3 that the electrical conductivity values were in a linear relationship. As seen in Figure 3, the lowest value of electrical conductivity was determined to be $14 \mathrm{~V} \mathrm{~cm}^{-1}$. 


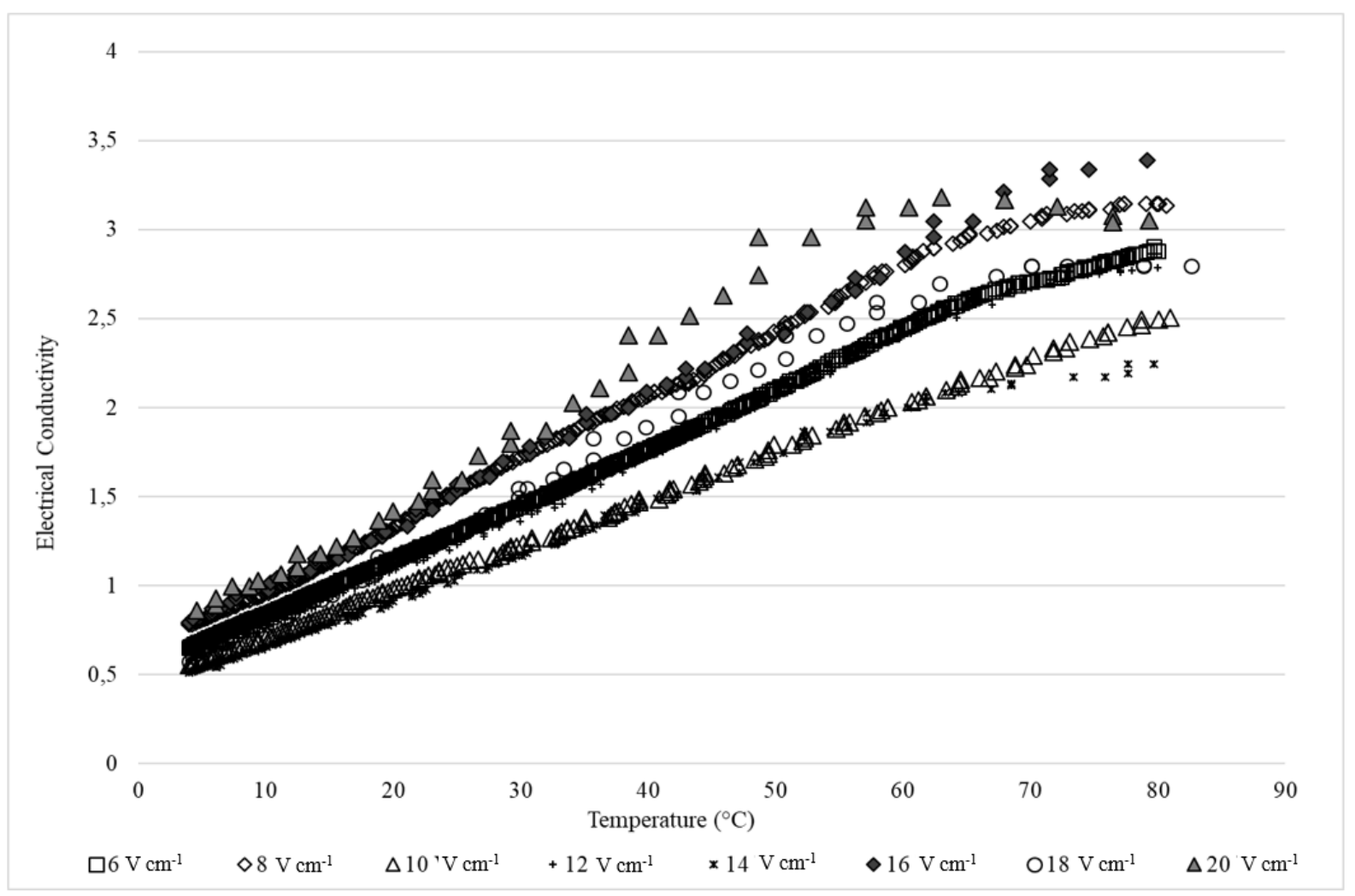

Figure 3. Electrical conductivity values of different voltage gradients during the ohmic cooking of the sucuk samples

It was known that increased voltage gradient, especially in liquid products, affected the electrical conductivity value positively. However, it was thought that the fat, ground beef, and spice mixtures in the product used might differ depending on the distribution. Because of this distribution, it was thought that the electrical conductivity value might have positive or negative effects.

Bozkurt and Icier, (2010a) cooked beef ground samples with different fat contents by applying different voltage gradients and investigated the change of electrical conductivity value during cooking. Increased fat content negatively affected the electrical conductivity value. They reported that the voltage gradient had no statistical effect on electrical conductivity. They also reported that the electrical conductivity value increased as the temperature increased, but not after the critical temperature. Zell et al., (2009b) cooked five different meat types (fresh meat cuts, pork, lamb, chicken, and turkey) by using ohmic heating in a constant voltage gradient $(20 \mathrm{~V}$ $\mathrm{cm}^{-1}$ ) and investigated the electrical conductivity value. They reported that the electrical conductivity value increased due to temperature increase for all meat samples. They also stated that fiber directions, minced meat, and salting of meat affected electrical conductivity.

\section{Temperature Homogeneity}

One of the essential parameters of the ohmic heating process is the homogeneity of the temperature distribution of the product. Although contact temperature measurements are taken from the product, there is a possibility of misleading due to the occurrence of regional warming. In the current study, the temperature distribution occurring in the entire product was investigated by determining the temperature distribution by the thermal camera. In the knowledge of the authors, it was determined that the homogeneity of solid products remained limited.

The thermal camera images of the temperature distribution obtained during cooking the sucuk samples using ohmic heating using eight different voltage gradients are given in Figure 4. It has been found that temperature homogeneity is not fully achieved in low voltage gradients. However, it was 
determined that the homogeneity of the temperature distribution was high due to the increased voltage gradients. Besides, in all voltage gradient applications, the temperature of the sucuk samples close to the surface was low. The main reason for this is that although the sucuk samples that have completed ohmic cooking have been quickly interrupted, the cut sample is thought to be due to the low temperature surrounding it. Since the ohmic cooking process is volumetric heating, it has been determined that there was some temperature increase in high voltage gradients even if ohmic heating was turned off. Therefore, it has been determined that the temperature value raised to 83-85 ${ }^{\circ} \mathrm{C}$. For this reason, it was determined that the area temperature was over $80^{\circ} \mathrm{C}$ (Fig. 4).

Icier et al., (2017) investigated the thawing of potato samples cut into cubes by using ohmic thawing and different thawing techniques with the help of a thermal camera. The images obtained by cutting the potato samples have reported that ohmic thawing did not provide a homogeneous dissolution as a result. Icier et al., (2014), the meatball sample was semicooked in three different voltage gradients using ohmic heating, and the temperature distribution homogeneity was examined with the help of a thermal camera by dividing it into two before, during, and after the cooking process. With the thermal data, it has been reported that it has a sufficient temperature distribution homogeneity for the cooking process. Bozkurt and Icier, (2010b) investigated ohmic cooking of ground beef samples with different fat contents in different voltage gradients. They determined cooking temperature homogeneity according to temperature ratios between center and surface temperatures. They reported that cooking using ohmic heating was fast and homogeneous cooking. They emphasized that the ohmic cooking process is more suitable than the traditional cooking process due to the low thermal conductivity of the meat samples.
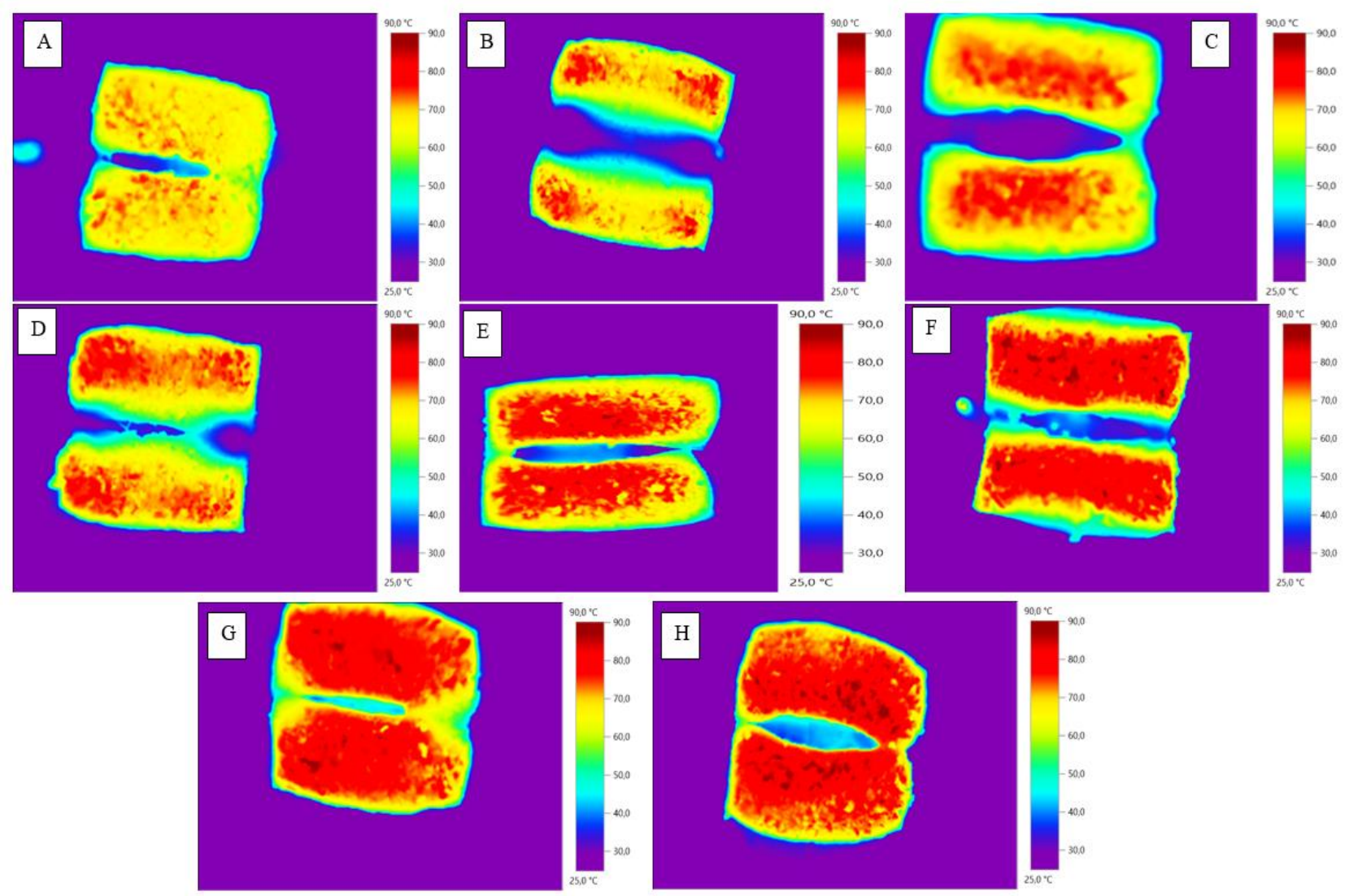

Figure 4. Temperature distribution of sausage samples in 8 different voltage gradients during ohmic cooking A: $6 \mathrm{~V}$ $\mathrm{cm}^{-1} ; \mathrm{B}: 8 \mathrm{~V} \mathrm{~cm}^{-1} ; \mathrm{C}: \mathrm{V} \mathrm{cm}^{-1} ; \mathrm{D}: 12 \mathrm{~V} \mathrm{~cm}^{-1} ; \mathrm{E}: 14 \mathrm{~V} \mathrm{~cm}^{-1} ; \mathrm{F}: 16 \mathrm{~V} \mathrm{~cm}^{-1} ; \mathrm{G}: \mathrm{V} \mathrm{cm}^{-1} ; \mathrm{H}: 20 \mathrm{~V} \mathrm{~cm}^{-1}$ 


\section{CONCLUSION}

The sucuk samples were cooked in eight different voltage gradients using ohmic heating. With the ohmic cooking, the processing time was shortened as the voltage gradient increased. It was determined that the electrical conductivity value ranged between 0.51-3.38 $\mathrm{S} \mathrm{m}^{-1}$ during the ohmic cooking process, and the electrical conductivity value increased as the temperature increased. The thermal camera determined temperature distribution homogeneity, and it was determined that the homogeneity value increased as the voltage gradient increased. Notably, the lack of performance and quality values of the effect of ohmic cooking with meat products is remarkable.

\section{CONFLICT OF INTEREST}

The Author report no conflict of interest relevant to this article

\section{RESEARCH AND PUBLICATION ETHICS STATEMENT}

The author declares that this study complies with research and publication ethics.

\section{REFERENCES}

Aksu, M. I., Kaya, M., 2004. Effect of usage Urtica dioica $L$. on microbiological properties of sucuk, a Turkish dry-fermented sausage. Food Control, 15(8):591595.

Bozkurt, H., Icier, F., 2010a. Electrical conductivity changes of minced beef-fat blends during ohmic cooking. Journal of Food Engineering, 96(1): 86-92.

Bozkurt, H., Icier, F., 2010b. Exergetic performance analysis of ohmic cooking process. Journal of Food Engineering, 100(4):688-695.

Bozkurt, H., Icier, F., 2010c. Ohmic cooking of ground beef: Effects on quality. Journal of Food Engineering, 96(4):481-490.

Castro, I., Teixeira, J.A., Salengke, S., Sastry, S.K., Vicente, A.A., 2004. Ohmic heating of strawberry products: Electrical conductivity measurements and ascorbic acid degradation kinetics. Innovative Food Science and Emerging Technologies, 5(1):27-36.

Cevik, M., Icier, F., 2018. Effects of voltage gradient and fat content on changes of electrical conductivity of frozen minced beef meat during ohmic thawing. Journal of Food Process Engineering, 41(4):1-13.

Cho, W.Il, Yi, J.Y., Chung, M.S., 2016. Pasteurization of fermented red pepper paste by ohmic heating. Innovative Food Science and Emerging Technologies, 34:180-186.

Cokgezme, Ö.F., Icier, F., 2019. Effect of voltage gradient on ohmic thawing characteristics of sour cherry juice concentrates for the temperature range of $-18^{\circ} \mathrm{C}$ to $+4^{\circ} \mathrm{C}$. Food science and technology international $=$ Ciencia y tecnologia de los alimentos internacional, 25(8):659-670.

Cokgezme, O.F., Sabanci, S., Cevik, M., Yildiz, H., Icier, F., 2017. Performance analyses for evaporation of pomegranate juice in ohmic heating assisted vacuum system. Journal of Food Engineering, 207:

Gavahian, M., Farahnaky, A., Sastry, S., 2016. Ohmicassisted hydrodistillation: A novel method for ethanol distillation. Food and Bioproducts Processing, 98:44-49.

Halden, K., De Alwis, A. .P., Fryer, P.J., 2007. Changes in the electrical conductivity of foods during ohmic heating. International Journal of Food Science \& Technology, 25(1):9-25.

İcier, F. 2010. Ohmic blanching effects on drying of vegetable byproduct. Journal of Food Process Engineering, 33(4):661-683.

İçier, F. 2003. Gıdaların ohmik 1sıtılmasının deneysel ve kuramsal olarak incelenmesi. Doktora Tezi, Ege Üniversitesi Fen Bilimleri Enstitüsü, İzmir.

İcier, F., Cokgezme, Ö.F., Döner, D., Bayana, D., Kaya, O., Çabas, B.M., 2020. Mathematical modelling of vacuum ohmic evaporation process. Innovative Food Science \& Emerging Technologies, 102560.

Icier, F., Cokgezme, O.F., Sabanci, S., 2017. Alternative thawing methods for the blanched/non-blanched potato cubes: microwave, Ohmic, and Carbon Fiber Plate Assisted Cabin Thawing. Journal of Food Process Engineering, 40(2)

İcier, F., Sengun, I.Y., Yildiz Turp, G., Arserim, E.H., 2014. Effects of process variables on some quality properties of meatballs semi-cooked in a continuous type ohmic cooking system. Meat Science, 96(3):1345-1354.

İçier, F., Yildiz, H., Sabanci, S., Cevik, M., Cokgezme, O.F., 2017. Ohmic heating assisted vacuum evaporation of pomegranate juice: Electrical conductivity changes. Innovative Food Science and Emerging Technologies, 39:241-246.

Palaniappan, S., Sastry, S.K., 1991. Electrical Conductivities of Selected Solid Foods During Ohmic Heating. Journal of Food Process Engineering, 14(3):221-236.

Sarang, S., Sastry, S.K., Knipe, L., 2008. Electrical conductivity of fruits and meats during ohmic heating. Journal of Food Engineering, 87(3):351356.

TFC, 2018. In Turkish food codex; (No: 2012/74). Retrieved from https://www.resmigazete.gov.tr/eskiler/2012/12/201 21205-12.htm

Yildiz-Turp, G., Sengun, I.Y., Kendirci, P., Icier, F. 2013, March 1. Effect of ohmic treatment on quality 
characteristic of meat: A review. Meat Science, 441448.

Yıldız, H., Icier, F., Eroglu, S., Dagci, G. 2016. Effects of electrical pretreatment conditions on osmotic dehydration of apple slices: Experimental investigation and simulation. Innovative Food Science and Emerging Technologies, 35:149-159.

Yildiz Turp, G., Icier, F., Kor, G. 2016. Influence of infrared final cooking on color, texture and cooking characteristics of ohmically pre-cooked meatball. Meat Science, 114: 46-53.

Zell, M., Lyng, J.G., Cronin, D. A., Morgan, D.J. 2009a. Ohmic cooking of whole beef muscle - Optimisation of meat preparation. Meat Science, 81(4):693-698.

Zell, M., Lyng, J.G., Cronin, D.A., Morgan, D.J. 2009 b. Ohmic heating of meats: Electrical conductivities of whole meats and processed meat ingredients. Meat Science, 83(3):563-570. 